\title{
Improving Teacher Competence in Questions on Google Forms Through In House Training (IHT) in the Era of the COVID-19 Pandemic at Candirejo State Elementary School, Kalibawang, Kulon Progo Regency
}

\author{
Paryati ${ }^{a, *}$ \\ a SD Negeri Candirejo, Kepiton, Banjarasri, Kalibawang Kulon Progo Daerah Istimewa Yogyakarta 55672, \\ Indonesia \\ *Corresponding author: paryati943@gmail.com
}

Received: August 30, 2020; Accepted: October 04, 2021; Published: October 15, 2021

\begin{abstract}
The purpose of this study is to improve the ability of teachers in preparing questions on google forms. Building teachers' practical ways of thinking in solving problems related to the preparation of HOTS questions, as well as increasing the professionalism of school principals in organizing In House Training (IHT) and increasing the motivation and competence of school principals during the COVID-19 pandemic. This research method is descriptive qualitative through school action research which further deepens the teacher development process related to writing HOTS questions on the google form. The data of this study are qualitative data, while the research subjects are Candirejo State Elementary School teachers, totaling 8 teachers consisting of 6 classroom teachers and 2 study teachers. The results showed that the teacher's ability to write written test questions was initially only 2 people (20\%), after the research was carried out with the first cycle of activities from 2 teachers to 8 teachers (100\%), while the research activities at the end the implementation of the second cycle of activities with an average score of 69.00 and an average score of 3.80, while based on presentation it reached $94.91 \%$. As for the stage of the second cycle of meeting 1 the teacher's ability in preparing questions through In House Training (IHT) on Google Form there was an increase of $2.14 \%$ and at the second meeting of cycle II it rose to $91.79 \%$ in the "Very Good" category. And the average score increased in the second cycle of meeting 2 to 64.25 from 61.38 . While the activities of IHT participants at the second meeting of the second cycle reached 22.50, the average value of the second cycle of the second meeting reached 3.75 while the percentage-based score reached $93.75 \%$ in the "Very Good" category. So that the research can be ended at the stage of cycle II for the second meeting.
\end{abstract}

Keyword: HOTS Question, Google Form, In House Training

\section{INTRODUCTION}

The 2016 Indonesian Government Regulation concerning the 2013 Curriculum states that the Directorate of Primary and Secondary Education, the Ministry of Education and Culture has issued a decree which forms the basis for educational units to implement the 2013 Curriculum. In the 2013 curriculum, the government also demands to be able to integrate learning with the use of Information Technology. and Communication. Utilization of Information and Communication Technology in the evaluation of learning is expected to improve the results of the evaluation. Utilization of technology with smartphones and laptops is expected to foster a sense of teacher interest in delivering assignments to students. Teachers carrying out assessments tend to be handwritten or typed using paper. The quality of the questions written on paper is still very low and has not shown the form of high-level thinking questions (HOTS). So, it's not surprising that during this pandemic, students feel bored with monotonous learning and delivering assignments. To overcome boredom, new things are needed with the internet, teachers in giving assignments/questions need to use Information and Communication Technology that is connected to the internet. The 
implementation of an assessment based on Information and Communication Technology if it is not implemented from now on will continue if the teacher does not try to develop his abilities.

Based on observations at Candirejo State Elementary School there are several problems that arose in the pandemic era in making HOTS questions based on information technology, including: Questions prepared by teachers were still conventionally written/typed manually, causing boredom and decreased achievement in students. The quality of the questions written on paper in general is still very low. Have not used the infrastructure at school, including the internet. The teacher does not yet know the effectiveness of using google forms in question assessment. Lack of training in schools to develop competence in compiling google form-based questions. Based on this description, the formulation of the problem in this research is whether the preparation of questions on Google Forms through In House Training (IHT) in the Era of the COVID-19 Pandemic at Candirejo State Elementary School, Kalibawang, Kulon Progo Regency can improve teacher competence, motivation and professionalism.

Competence is the basic ability possessed by a person which includes aspects of knowledge, skills and work attitudes in accordance with established standards. Competence is a work ability that has values, a demonstrated knowledge base, cognitive, affective and psychomotor behavior. The competence of the principal in carrying out his duties as the manager of the education unit must have the knowledge, attitudes and skills to explain several aspects or domains contained in the concept of competence. Assessment is defined as a process taken to obtain information that is used in order to make decisions about students, curriculum, programs and educational policies, methods or other educational instruments by an official body, institution, organization or institution that organizes a particular activity [1].

Assessment is an integral part of learning to make a significant contribution to learning [2]. Assessment is the process of collecting and processing information to measure the achievement of student learning outcomes. Assessment can also be interpreted as a process to collect information whose results are processed to measure the achievement of student learning outcomes.

Higher-order thinking skills involves critical and creative thinking guided by ideas of truth, each of which has meaning [3]. Critical and creative thinking are interdependent as are the criteria and values of reason and emotion. The Higher Order Thinking Skills (HOTS) questions are measurement instruments used to measure higher order thinking skills, namely the ability to think that does not just recall, restate, or refer without processing (recite). The questions designed to measure higher order thinking skills through processing activities, not just remembering and practicing [4].

The Higher Order Thinking Skills (HOTS) is a way of thinking that no longer only memorizes verbally but also interprets the nature of what is contained among them, to be able to interpret meaning requires an integralistic way of thinking with analysis, synthesis, association to draw. conclusions towards the creation of creative and productive ideas [5]. The higher order thinking skills can occur when a person associates newly received information with information already stored in his memory, then connects it or rearranges and develops the information so that a goal or a settlement of a situation is achieved hard to solve [6].

Higher Order Thinking Skills (HOTS) is the ability to think not just remember, restate, also refer without doing processing, but the ability to think to examine information critically, creatively, creatively and able to solve problems. Through online learning students can learn to find alone and able to think at a higher level.

The Google form is a worksheet application that can be used independently or collectively for the purpose of processing user information files [7]. Technological developments require changes in the teaching and learning process, including giving online assignments via cellphones. During the COVID-19 pandemic, it is very possible to give assignments or questions with the google form application. Google Form can be used as one of the innovative and effective learning media in delivering material content from individuals and groups.

The competence that must be possessed by teachers is the ability to conduct assessments, both on the process and use of learning media [8]. Data obtained in several schools in self-development activities in the preparation of assessment instruments as an effort for school exams shows that most classroom teachers lack the ability to evaluate using Google Form application technology. It is shown that there are questions that are only copied from the Student Worksheets distributed by publishers. A similar condition occurred at SD Negeri Candirejo Kalibawang. The author found the findings during the evaluation of the writing of the questions that were arranged identically to the questions from other schools in the same and still photocopies. Ideally in this era of globalization, when the government prepares the golden generation in 2045, teachers must be able to equip students with various skills which include the concept of Higher Order Thinking Skills (HOTS). 
The use of google forms in compiling HOTS questions aims to improve teacher competence at Candirejo Kalibawang Elementary School. in the preparation of questions on the google form through "In House Training (IHT)". Based on the school exam grid, a teacher is required to be able to develop various assessment instruments that are adequate to be able to comprehensively reveal the abilities of students. The form of questions that are able to express the cognitive level is known as HOTS questions.

The teacher's ability to write HOTS questions on the google form can be seen from the knowledge dimension, generally HOTS questions measure the metacognitive dimension, not just measuring the factual, conceptual, or procedural dimensions. The metacognitive dimension describes the ability to connect several different concepts, interpret, solve problems (problem solving), choose problem solving strategies, find (discovery) new methods, argue (reasoning), and make the right decisions. The dimensions of the thought process of Bloom's Taxonomy consist of the following abilities: knowing (knowing-C1), understanding (understanding-C2), applying (applying-C3), analyzing (analyzing-C4), evaluating (evaluating-C4). C5), and creating (C6). HOTS questions generally measure abilities in the realms of analyzing (analyzing-C4), evaluating (evaluating-C5), and creating (creating-C6) [9]. After validating the preparation of HOTS questions, it is hoped that the principal will be able to carry out activities internally In House Training IHT to improve the ability of teachers to prepare questions.

In House Training (IHT) is a training program held in schools by optimizing the potential that exists in schools, using work equipment for training participants with relevant materials and problems being faced during the COVID-19 pandemic, so that participants are expected to students can more easily absorb and apply material to solve and overcome problems related to assignments and are able to directly improve their quality and performance [10]. The purpose of In House Training (IHT) is to improve the quality of human resources utilized by relevant agencies, so as to better support efforts to achieve the goals that have been set. The target of internal training is to create interaction between students in the relevant school environment, as well as strengthen a sense of kinship or togetherness, increase motivation, both for participants and resource persons to get used to a continuous learning culture, explore problems faced in the field related to increasing work effectiveness during the pandemic. COVID-19 Training is expected that teachers can help each other in preparing questions through the google form. The teacher can ask for help from other teachers to solve the problem, by writing HOTS questions and operating the google form, which he is facing, in this way the quality of the preparation of questions through the teacher's google form can be of higher quality. Based on this background, this research aims to improve the ability of teachers in preparing questions on google for

\section{RESEARCH METHODS}

This research is a School Action Research carried out at the school level, and its implementation is to improve the competence of school principals in managing learning leadership through continuous "In House Training" (IHT) during the COVID-19 pandemic. School action research for problem solving with a scope that is not too broad is related to the problems faced by school principals in learning leadership. Researchers took this research starting with the problem of educational practice during the COVID-19 pandemic, and it could also be started with ideas for making changes, the changes were directed at increasing the competence of principals in administrative management in schools related to the assessment of learning outcomes in this case. preparation of questions on google forms during the COVID-19 Pandemic.

The subjects of this study were Candirejo State Elementary School teachers, totaling 8 teachers consisting of 6 classroom teachers and 2 study teachers. The 8 teachers are 5 female teachers and 3 male teachers. The Candirejo State Elementary School teachers who are the research subjects are all educational S1 certificates.

The object of research as the basis for conducting research is something that is the focus of attention in research, how research improves teacher competence in compiling questions in google form and implementing it to students through distance learning during the COVID-19 pandemic at Candirejo Kalibawang Elementary School through "In House" activities. Training" (IHT). This research was carried out for 3 months, starting from January to March 2021.

This research method uses descriptive qualitative research. The analysis further deepens the teacher development process related to writing HOTS questions on the google form. This research data is qualitative data, meaning that researchers are interested in the process, meaning and understanding 
obtained through words or pictures based on data analysis. The researcher used a spiral model research design consisting of two cycles, each cycle using four components of action, namely Planning, Action, Observation and Reflection in a spiral that are interrelated. The research plan for each cycle and each meeting can be seen in Figure 1.

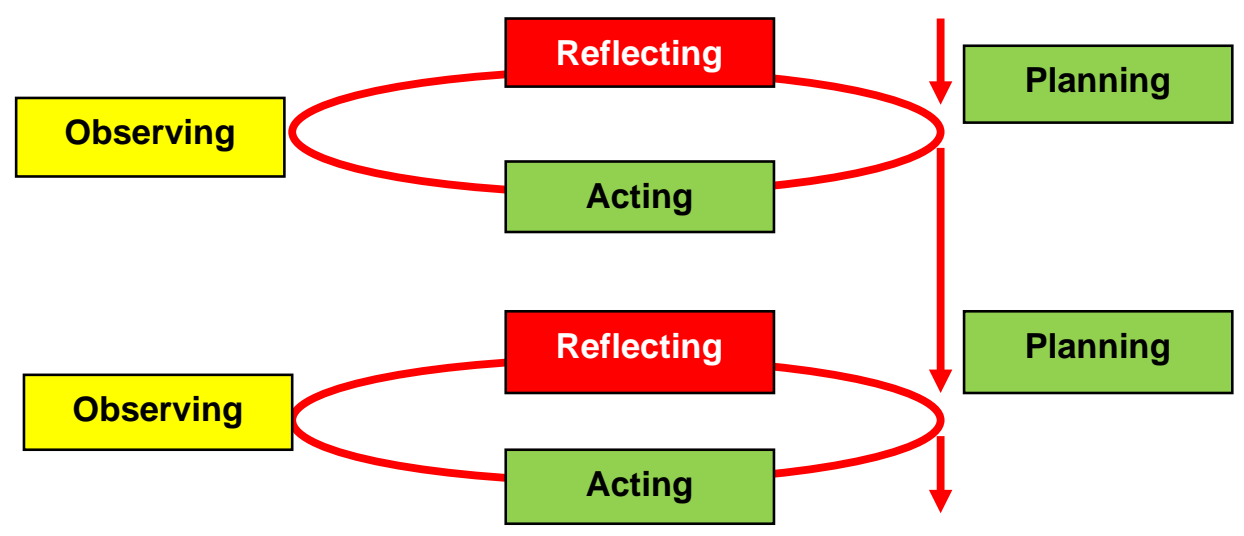

Figure 1. Kemmis and Mc Taggart Spiral Model [11]

School action research data collection techniques in order to increase teacher competence in compiling HOTS questions on google form through IHT activities at Candirejo State Elementary School. The data analysis technique uses the average of the observations, then the average results are described for each instrument. This descriptive analysis is used to describe the characteristics of the research data and answer the problems listed in the problem formulation. The descriptive analysis used in this study for the data analysis of the item review is the minimum score, maximum score, average, and percentage. Based on the criteria, if it reaches a minimum score of 85 for a scale of 100 , while for observing the activities of IHT participants and observing the activities of researchers, the achievement value is said to be successful if the average percentage reaches a value of more than or equal to $85 \%$.

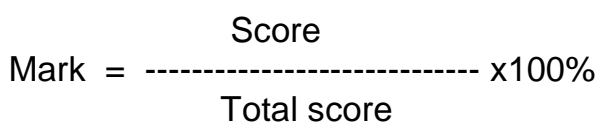

Table 1. Criteria of each aspect

\begin{tabular}{cc}
\hline Criteria & Score Range \\
\hline Very Good & $90<\mathrm{AB} \leq 100$ \\
Good & $80<\mathrm{B} \leq 90$ \\
Enough & $70<\mathrm{C} \leq 80$ \\
Not Enough & $\leq 70$ \\
\hline
\end{tabular}

\section{RESULTS AND DISCUSSION}

From the results of observations made with the academic supervision activities of class visits to eight teachers, the researchers obtained information that all teachers (eight people) were declared unable to prepare HOTS questions through Google Forms in assessing student learning outcomes during the COVID-19 pandemic properly. and right. The results of observations in the initial conditions are as described in Table 2.

Based on Table 2, it can be explained that in the initial conditions, 8 teachers or $100 \%$ were stated to have not been able to compile HOTS questions on the google form in carrying out the assessment of learning outcomes correctly. Classically, the increase in the ability of teachers in carrying out HOTS question preparation activities on google forms related to the assessment of learning outcomes has not met 
the criteria for success, because they only obtained 29.74 with the criteria "Less". This shows that the acquisition of these results is still below the success criteria, namely at least getting a score of 85 or more with the minimum criteria of "Good".

Table 2. Recapitulation of Teacher Capacity Building in compiling HOTS Questions on Google Form Candirejo State Elementary School.

\begin{tabular}{clcc}
\hline No & \multicolumn{1}{c}{ Teacher } & $\begin{array}{c}\text { Achievement } \\
\text { Percentage }\end{array}$ & $\begin{array}{c}\text { Result } \\
\text { Criteria }\end{array}$ \\
\hline 1 & First Class & 28.33 & Not Enough \\
2 & Second Class & 25.33 & Not Enough \\
3 & Third Class & 33.45 & Enough \\
4 & Fourth Class & 29.21 & Not Enough \\
5 & Fifth Class & 26.33 & Not Enough \\
6 & Sixth Class & 38.33 & Enough \\
7 & Sport and Health Education & 27.46 & Not Enough \\
8 & Islamic Education & 29.45 & Not Enough \\
\hline & Average & $\mathbf{2 9 . 7 4}$ & Not Enough \\
\hline
\end{tabular}

The IHT activity in this study aims to help improve teacher competence in the preparation of HOTS questions needed as a learning evaluation tool. This program can be carried out by the principal with the intention of providing assistance and services to teachers to improve and improve the quality of the preparation of questions in order to obtain better results this is shown based on the results of observations in the form of the following data:

1. Implementation of In House Training

Table 3. Implementation of In House Training (IHT) Preparation of Questions in Google Form Cycles I and II at SD Negeri Candirejo Kalibawang

\begin{tabular}{clcccc}
\hline No. & \multicolumn{1}{c}{ Activity } & $\begin{array}{c}\text { Total } \\
\text { score }\end{array}$ & $\begin{array}{c}\text { Average } \\
\text { Value }\end{array}$ & $\begin{array}{c}\text { Average } \\
\text { Percent }\end{array}$ & Criteria \\
\hline $\mathbf{1}$ & Cycle I & & & & \\
& First Meeting & 63.00 & 3.54 & 88.43 & Good \\
& Second Meeting & 66.00 & 3.67 & 91.67 & Very Good \\
2 & Cycle II & & & & \\
& First Meeting & 66.00 & 3.59 & 89.81 & Very Good \\
& Second Meeting & 69.00 & 3.80 & 94.91 & Very Good \\
\hline
\end{tabular}

Based on the analysis of research data in Table 3, it shows that the level of development of the principal's teacher's ability as a researcher in conducting IHT greatly affects the teacher's ability to prepare HOTS questions as in the data acquisition above, it shows an increase in cycle I meeting 1 to cycle II meeting 2 by $6,48 \%$. In the end, the second meeting of cycle II the average number reached 69.00 , and the average score was 3.80, while based on the presentation it reached $94.91 \%$.

2. Teacher's ability in compiling HOTS questions on Google Form.

The results The results showed that there is a decrease when corrective action is taken on the indicators of the preparation of the grid of participants' questions that have decreased so that it affects the acquisition of scores. After discussing with the research collaboration, improving by repeating the IHT material, the participants showed an increase in the second cycle of meeting 1 there was an increase of $2.14 \%$ and at the second meeting of cycle II it rose to $91.79 \%$ in the "Very Good" category. The number of average scores increased in the second cycle of meeting 2 to 64.25 from 61.38 . 
Table 4. Teacher's ability in compiling HOTS questions on Google Form cycles I and II at Candirejo State Elementary School

\begin{tabular}{clcccc}
\hline No & Kegiatan & Total score & $\begin{array}{c}\text { Average } \\
\text { Value }\end{array}$ & $\begin{array}{c}\text { Average } \\
\text { Percent }\end{array}$ & Criteria \\
\hline \multirow{1}{1}{} & Cycle I & & & & \\
& First Meeting & 61.38 & 4.38 & 87.68 & Good \\
& Second Meeting & 61.25 & 4.38 & 87.50 & Good \\
\multirow{4}{*}{ Cycle II } & & & & \\
& First Meeting & 62.75 & 4.48 & 89.64 & Good \\
& Second Meeting & 64.25 & 4.59 & 91.79 & Very Good \\
\hline
\end{tabular}

3. In House Training (IHT) Participant Activities Compilation of Questions on Teacher's Google Form at Candirejo State Elementary School.

The results of research related to the activities of participants participating in In House Training (IHT) preparation of questions on google form obtained data based on the results of observations of participant activities in Table 5.

Table 5. In House Training (IHT) Participant Activities Compilation of Questions in Google Form Cycle II Meeting 2 Teachers at Candirejo State Elementary School.

\begin{tabular}{|c|c|c|c|c|c|}
\hline No. & Kegiatan & Total score & $\begin{array}{c}\text { Average } \\
\text { Value }\end{array}$ & $\begin{array}{l}\text { Average } \\
\text { Percent }\end{array}$ & Criteria \\
\hline \multirow[t]{3}{*}{1} & Cycle I & & & & \\
\hline & First Meeting & 21.38 & 3.56 & 89.06 & Good \\
\hline & Second Meeting & 21.38 & 3.56 & 89.06 & Good \\
\hline \multirow[t]{3}{*}{2} & Cycle II & & & & \\
\hline & First Meeting & 22.25 & 3.71 & 92.71 & Very Good \\
\hline & Second Meeting & 22.50 & 3.75 & 93.75 & Very Good \\
\hline
\end{tabular}

The results showed that the participants' activities in participating in the IHT activities in the preparation of HOTS questions were good and orderly, it was proven that the average score of the 2nd cycle II meeting reached 22.50, the second cycle 2nd meeting average score reached 3.75 based on the percentage $93.75 \%$ with "very good" category.

4. Interview

From the results of the interviews, it was shown that the In House Training (IHT) participants in the preparation of questions in the Google Form Cycle I and II Teachers at SD Negeri Candirejo Kalibawang conducted by researchers were very useful for teachers. and teachers must be able to master IT, especially the "Google Form" application in the application of distance learning in the era of the COVID-19 pandemic, and the ability to compose HOTS questions still needs improvement and additional activities are carried out to assist teachers in compiling HOTS questions.

\section{CONCLUSION}

Research shows that In House Training (IHT) activities are proven to improve teachers' abilities in preparing written test questions. This is indicated by the results of the teacher's ability to write written test questions which were initially only 2 people (20\%), after the first cycle activities were carried out from 2 teachers to 8 teachers $(100 \%)$, while the research activities at the end of the activity the implementation of the second cycle which the average number reached 69.00, and the average score was 3.80, while based on the presentation it reached $94.91 \%$. As for the stage of the second cycle of meeting 1 the teacher's ability in preparing questions through In House Training (IHT) on Google Form there was an increase of $2.14 \%$ and at the second meeting of cycle II it rose to $91.79 \%$ in the "Very Good" category. And the average 
score increased in the second cycle of meeting 2 to 64.25 from 61.38. While the activities of IHT participants at the second meeting of the second cycle reached 22.50, the average value of the second cycle of the second meeting reached 3.75 while the percentage-based score reached $93.75 \%$ in the "very active" category. So that the research can be ended at the stage of the second cycle of the second meeting.

\section{REFERENCES}

1. U.B. Hamzah and S. Koni, Assessment Pembelajaran. (Bumi Aksara, Jakarta, 2012)

2. A.I. Richard. "Learning To Teach" (Terjemahan Belajar Untuk Mengajar) (Pustaka Pelajar, Yogyakarta, 2008)

3. W.S. Kuswana, "Taksonomi Kognitif Perkembangan Ragam Berpikir" (PT Remaja Rosdakarya Offset, Bandung, 2012)

4. S. Wiwik. Buku Penilaian Beroerientaasi Higher Order Thinking Skills (Direktorat Jendral Guru dan Tenaga Kependidikan Kementerian Pendidikan dan Kebudayaan, Jakarta, 2018)

5. L. Ernawati. "Pengembangan High Order Thinking (HOT) Melalui Metode Pembelajaran Mind Banking Dalam Pendidikan Agama Islam. Proceeding of International Conference on Islamic Civilization Ans Society (ICICS). (Darul 'Ulum Islamic University, Lamongan, 2017), pp.189-202

6. Rosnawati. Kemampuan penalaran matematika siswa SMP Indonesia pada TIMSS 2011. Prosiding Seminar Nasional Penelitian, (Pendidikan dan Penerapan MIPA, Fakultas MIPA, Universitas Negeri Yogyakarta, 2013) pp.1-6.

7. Arifin, Zainal. 2011. "Konsep dan Model Pengembangan Kurikulum". Bandung: Remaja Rosdakarya.

8. C.Marsh. "Handbook For Beginning Teachers.Sydney": (Addison Wesley Longman Australia Pry Limited, Australia, 1996)

9. L.W. Anderson and D.R. Krathwohl. A Taxonomy for Learning, Teaching, and Assesing: A Revision of Bloom's Taxonomy of Educatioanl Objectives. (Addison Wesley Longman, Inc, New York, 2001)

10. H. Basri and A. Rusdiana, Manajemen Pendidikan \& Pelatihan. (CV Pustaka Setia, Bandung, 2015)

11. J.W. Creswell. Research Design: Pendekatan Kualitatif, Kuantitatif dan Muxied. (Pustaka Pelajar, Yogyakarta, 2012) 